\title{
Introduction
}

\section{Securing Refugee Protection in a Cold Climate}

\author{
Colin Harvey
}

$\mathrm{T}$ he terrible events of September 11, 2001, in the U.S. continue to have an impact on the treatment of refugees and asylum seekers in a range of states. This is despite the fact that little evidence has been produced to demonstrate any link between international terrorism and refugee movements in, for example, Canada or theU.S. The suspicion is that governments have used events to justify the accelerated implementation of policies which were already being considered, or have applied existing authorities inappropriately in this new context. Through such cynical manipulation of this tragedy governments too display a lack of respect for the victims of international terrorism.

Governments have a duty to protect their citizens. Citizens have the right to expect to be protected. Those who support a "social contract" model of democratic life affirm not only the duties of the citizen, but also the responsibilities of the state. That governments come under intense pressure to offer security to their citizens is not in doubt. $\mathrm{N}$ o one disputes the role of the state in securing the conditions which make a decent human life possible.

Terrorism often brings with it vocal demands for tough responses. In thecase of internal opposition movementsthe focus is on the perceived "enemy within." Responses can take the form of enhanced monitoring of political movements and/or national minorities. H owever, when thedanger comes from international terrorism then attention often shifts to migration control, and with it more intense scrutiny of the regulation of entry and the monitoring of migrants who are already present. What is sometimes neglected is that this does not take place in a legal vacuum. States have obligations arising from national and international law which apply to citizens and non-citizens. In particular, human rights law is there to offer protection to persons. It may seem obvious, even banal, but it is the human element which makes human rights so important. One of the more dispiriting current political themes is the vilification of human rights advocates, and the downgrading of human rights considerations in the formulation of policy responses. This is a hard time to be a human rights lawyer and/or activist. What is remarkable is that states that paradetheir adherence to therule of law in theinternational community treat human rights law (and human rights lawyers) with contempt when it is convenient to do so. It is almost as if the struggle to enshrine human rights in law had never happened. A similar trend is also evident with respect to those who call for the full and effective imple mentation of refugee law. The danger is that the gains in refugee and human rights law are threatened by states that view them as inconvenient constraints.

The contributors to this special issue of Refuge offer insights into the responses to the events of September 11 which have impacted on refugees and asylum seekers. If there is a unifying theme, it is the importance of defending basic humanitarian principles at a time when they are coming under intense strain. All the contributors acknowledge the need to address international terrorism. This is not in dispute. What is problematic is the way basic human rights principles have been lost in the process. Governments often talk of a balance. However, when one looks at the evidence, human rights are frequently at the bottom of the list when national security becomes an issue. In addition, it should be remembered that in law at least some rights really are absolute. In Europe, for example, Article 3 of the European Convention on H uman Rights provides an absolute guarantee against return. Most human rights do not take this form. Limitations are permitted, for example, to the right to liberty and security of the person. Refugee law also contains permissible limitations and even allows 
exclusion from status in a range of cases rel evant to this special issue. H owever, the point is that state policy is constrained by established norms of refugee and human rights law.

Howard Adelman examines the control mechanisms in placeto restrict theentry and retention of terrorists through the refugee determination process in Canada. He asks whether refugees are a security issue or not and places the current debate in context. $\mathrm{H}$ is answer to his own question is straightforward. Hestates that thereis no evidenceto link global terrorism with refugees. However, he argues that homeland insurgency movements have used the determination process to ensure that their supporters gain entry to Canada. The conclusion reached by Adelman is that the security threat has been used to achieve other objectives, such as reducing the number of refugee claimants coming to Canada.

Audrey Macklin explores the troubling level of judicial deference evident after September 11. Her focus is on Suresh v. Canada ( $M$ inister of Citizen ship and Immigration) ${ }^{1}$ and A hani v. Canada (M inister of Citizen ship and Immigration). ${ }^{2}$ The argument is that when there is a perceived threat to democratic states the role of the judiciary becomes particularly important. Are judges prepared to uphold established norms in a difficult political context? In trying to answer this she focuses rather more on Ahani than on Suresh. This is deliberate. Macklin argues that Ahani has more to tell us about the position of refugees labelled as security threats. In this instance, M acklin's assessment is that the judges failed to accord sufficient weight to the human rights of the individual. In this the Canadian Supreme Court is not alone in the common law world. ${ }^{3}$

Kate $\mathrm{M}$ artin carries forward the theme of human rights sacrificed to security interests. She examines the response of the U S. government to the events of September 11. This contribution makes for depressing reading. The policy response remains remarkable for its neglect of basic civil liberties. M artin highlights the use of preventive detention and the decision to keep the names of those detained a secret. She notes the unconstitutional and generally questionable way that pre-existing authorities were used to justify this policy. The U.S. repeated a common flaw in anti-terrorism policy by adopting what she terms a "dragnet approach" rather than a targeted investigation focusing on the actual terrorist threat. $M$ artin argues that promoting democracy, justice, and human rights is as powerful a weapon as military strength. $\mathrm{H}$ er conclusion is that theU.S. government has assigned no weight to the protection of civil liberties in its current policy response. It is hard to disagree with this conclusion.

Reg Whitaker provides a welcome reminder that we should not exaggerate the current position. As he notes, journalistic wisdom is that the world has changed forever. $\mathrm{H}$ e is suspicious of some of these overblown claims. In fact, he suggests that we are seeing an acceleration of trends al ready evident before September 11 . Whitaker acknowledges the real pressures placed on governments by international terrorism. He also suggests that North American governments have learned some lessons from the mistakes of the past. As henotes, this will be of littlecomfort to those at the receiving end of a security strategy which is effectively based on ethnic profiling.

Raquel Freitas looks at the concept of "human security" and argues that it is difficult to combine with the understandings of internal security which have emerged since September 11 . She stresses the complexity of the term and its use. Freitas is worried about a concept which is so open to abuse and argues that it can easily turn into an instrument of exclusion. In the current climate it is easy to see what she means. However, the "human security" model remains important, particularly when considering how theroot causes of forced migration might be effectively addressed.

Suman Bhattacharyya provides a useful report of an important meeting organized by the Canadian Centre for Foreign Policy Development and the Centre for Refugee Studies on migration and security after September 11. A number of recommendations emerged from this meeting. Generally, the policy makers involved accepted the continuing importance of the "human security" model. In practice, and as outlined, this means focusing on the root causes of migration. In addition, Bhattacharyya outlinesthe acceptance of the need for more economic migration. It is clear from this contribution that human rights considerationsformed a central part of the discussions. In particular, whatever other states may wish to do, Canada should not violate its international obligations.

Ultimately, political responses are the only effective way to address security threats. Military responses may satisfy short-term ambitions, but in thelonger term it is to politics that we should turn for a solution. Conflict prevention is therefore one part of a rational policy response. Erin Baines offers an instructive interview with Peter Uvin on the lessons to be learned from the Rwandan experience. Uvin advances seven features that ought to be part of a good policy on development and conflict prevention. $\mathrm{H}$ is reference to a human rights based approach is of particular interest. U vin talks not of a legalistic model, but of creating social practices that might make rights real. This is an attractive way of thinking about human rights. Political imagination is sometimes eroded by a more narrow legal logic. In the process the social basis of human rights law is often lost. Uvin is right, in my view, to stress the creation of new social practices. H owever, what emerges is the sense 
that too much is still happening "after the event" and that too often conflict prevention is never seriously attempted. This seems to be because we are still not listening to the "voices" of people in local contexts.

The contributors to this issue of Refuge all have different things to say about current developments. They write from a range of perspectives. What is revealing is that common themes do emerge. In particular, there is a general concern that human rights and civil liberties have been sacrificed in an attempt to address security threats. W riting from a U.K. perspective, I can confirm that this trend has been repeated here and in the European Union as a whole. In order to facilitate the policy of detention of asylum seekers, the U.K. government decided to derogatefrom Article 5 of theEuropean Convention on Human Rights. The U.K.'s Anti-terrorism, Crime and Security Act 2001 includes extensive provisions on the treatment of asylum seekers deemed to be international terrorists. Asylum seekers have steadily been constructed as a security threat, and are now routinely discussed as part of the focus on tackling forms of criminality. Despite the vocal claims to the contrary by states, the institution of asylum is now under serious threat in Europe.

The negative impact of recent legal developments on refugees and asylum seekers is unsurprising given the existing trends. Governments haveused theevents of September 11 to justify the rapid implementation of plans that were al ready being discussed. By using the plight of victims as a means to justify illiberal ends states display a level of disrespect for those who suffer from international terrorism.

At times like this we all must acknowledge the force of the human in human rights. We also should stand up for established protections. What are human rights or civil liberties worth if when placed "under stress" they aresimply swept aside? No one doubts the importance of protecting people from international terrorism. As a number of contributors point out, democracy, justice, and human rights are also important tools to be used in this struggle. Whether it is Canada, the U.S., or the U.K., it is vital that fundamental freedoms and the core values of democratic life are not sacrificed for short-term political ends. Politicians, lawyers, judges, and NGOs (to name only a few) all have a responsibility to ensure that this does not happen. Refugees and asylum seekers should not become victims of the events of September 11.

\section{Notes}

1. 2002 SCC 1.

2. 2002 SCC 2 .

3. See Secretary of State for the Home Department v. Rehman [2001] 3 WLR 877.
Colin Harvey is professor of constitutional and human rights law at the U niversity of Leeds (U.K.). His research interests include refugee and asylum law, human rights, and constitutional law and politics. 